\title{
Comparison between Organic and Mineral Sources of Potassium and Their Effects on Potassium Fractions in Clay Soil and Productivity of Potato Plants under Water Stress Conditions
}

\author{
Shaimaa H. Abd-EIrahman ${ }^{1 *}$ and Noura M. Taha ${ }^{2}$ \\ ${ }^{1}$ Department of Soil Science, Faculty of Agriculture, Ain Shams University, Egypt \\ ${ }^{2}$ Department of Horticulture, Faculty of Agriculture, Ain Shams University, Egypt
}

\begin{abstract}
Dotassium $(\mathrm{K})$ is an essential element for plant growth that maintains water balance within its cells. Different forms of K were investigated for their effects on potato (Solanum tuberosum, cv. Spunta) plants grown under water stress conditions as a kind of adaptation to the climatic changes and water shortage under Egyptian soil conditions. Also, knowledge of different $\mathrm{K}$ fractions in the studied clay soil is important to achieve the sustainability in agriculture. Therefore, a field experiment was conducted during the two tested seasons of years 2014 and 2015 at the Faculty of Agriculture, Ain Shams University, Qalubia governorate, Egypt. Two sources of $\mathrm{K}$ were tested under three levels of irrigation water in a split-plot design. Results indicated that $\mathrm{K}$ fractions in soil were in order of total $\mathrm{K}>$ non-exchangeable/ fixed $>$ exchangeable $>$ water soluble. The $50 \%$ irrigation level of irrigation requirements (IR) combined with K-humate as ground application increased water soluble and exchangeable $\mathrm{K}$ in the studied soil. While there was hardly no changes observed due to the applied treatments on fixed and total amounts of $\mathrm{K}$ in the soil. Regarding the studied vegetative growth and yield parameters of the growing potato plants, the treatment $100 \%$ of IR combined with K-humate as soil application caused significant increases. The specific gravity of tuber, as an important indicator of potato tuber quality, recorded the highest value by applying $50 \%$ of IR combined with K-humate as ground addition, compared to mineral addition which came in the second order. Regarding the nutrient concentrations in potato haulm, results revealed that the $50 \%$ of IR combined with K-humate gave the highest content of $\mathrm{N}$, while the same irrigation level with K-humate plus foliar spray gave the highest content of $\mathrm{P}$ and $\mathrm{K}$, during the two tested seasons. In tubers, $50 \%$ of IR combined with K-humate as soil application gave the highest concentration of $\mathrm{N}$ and $\mathrm{P}$ during the two tested seasons, while $75 \%$ of IR in the first season and $50 \%$ of IR in the second season combined with K-humate plus foliar spray gave the highest values of $\mathrm{K}$ content. The calculated water use efficiency (WUE) showed that the highest value was obtained by $50 \%$ irrigation level of IR combined with soil application of K-humate.
\end{abstract}

Keywords: Potassium humate, Potassium sulphate, Ground application, Foliar application, Potassium fractions in clay soil, Productivity of potato plants, Irrigation water levels.

\section{Introduction}

Potato (Solanum tuberosum L.) is one of the common vegetable in Egypt. Their tubers are good sources of carbohydrates, proteins, vitamins and minerals (Blagoeva et al., 2004). The quality of potato tubers as well as their chemical composition are mostly influenced by many factors e.g. soil fertility and the used agrochemicals (Rytel et al., 2013). Potassium is an essential nutrient for plant growth that influences synthesis, location, transformation and storage of carbohydrates, tuber quality and processing characteristics as well as plant resistance to stresses and diseases (Ebert, 2009). Although, the reserved $\mathrm{K}$ in the soil is generally high; however, most of its concentrations are incorporated within the crystal lattice structure of the clay minerals thus being unavailable to plants (Zörb et al., 2014). Therefore, additional K-containing sources are necessary to sustain optimal plant growth performance and yield components (Zörb et al., 2014). In this concern, potassium humate

*Corresponding author: Shaimaa_Hassan@agr.asu.edu.eg DOI : 10.21608/ejss.2018.2752.1153

(C)2018 National Information and Documentation Center (NIDOC) 
(an organic fertilizer) is thought to be a safer $\mathrm{K}$-amendment in food production than potassium sulphate (mineral fertilizer). This amendment not only improves the product quality, but also increases the plant tolerance towards disease, pests and other environmental stresses such as heat, cold and drought (Ajalli et al., 2013). Also, it can increase the nutrient content of soil and growing plants, which is reflected in increasing fertilizer use efficiency (Mosa, 2012).

Egypt has already reached the water poverty limit and needs a much greater share of Nile water in year 2050 to cover the shortage and face the increment in requirements due to increase population. Also, surface freshwater pollution has embarked on a critical path. So, it is necessary to reduce consumption of water irrigation (ElRamady et al., 2013). Potato is a sensitive crop to water stress (Onder et al., 2005). Thus, the irrigation schedule should be managed in combination with optimized fertilizer applications to ensure high productivity of the potato yields. An application of $\mathrm{K}$ fertilizers $\left(120 \mathrm{~kg} \mathrm{~K} \mathrm{ha}^{-1}\right)$ under controlled deficit irrigation $(80 \%$ of soil field capacity) improved the quantity and quality of potato yield, together with elevated WUE (Abd El-Latif et al., 2011). Moreover, Mosa (2012) reported that amending soils with potassium humate can increase the moisture retention in the root zone, and therefore improves the irrigation efficiency.

Thus, the main objective of this study was to evaluate the effect of $\mathrm{K}$ fertilization from different sources (organic and mineral), and applied with different methods (ground and foliar applications) on $\mathrm{K}$ fractions and productivity of potato plants grown in clay soil under different irrigation water levels.

\section{Materials and Methods}

The current study was carried out during the two successive autumn seasons of the years 2014 and 2015 at the experimental farm of Faculty of Agriculture, Ain Shams University, Qalubia Governorate, Egypt. The average temperature was $20 \pm 4.5^{\circ} \mathrm{C}$, the relative humidity was $62 \pm 7 \%$ and the evapotranspiration rate $\mathrm{ET}_{\mathrm{o}}$ was $3.5 \pm 1.6$ $\mathrm{mm}$ day $^{-1}$. The investigated soil was a clayey one (Vertic Torrifluvents) and its physical and chemical properties were determined, before cultivation, by the standard methods outlined by Klute (1986) and Page et al. (1982) and the obtained results are shown in Table 1.

TABLE 1. Some physical and chemical properties of the studied soil $(0-30 \mathrm{~cm})$

\begin{tabular}{|c|c|c|c|}
\hline Particle size distribution, \% & & Soluble ions, $\operatorname{mmol}_{c} \mathbf{L}^{-1}$ & \\
\hline Sand & 21.9 & $\mathrm{Ca}^{2+}$ & 3.00 \\
\hline Silt & 23.6 & $\mathrm{Mg}^{2+}$ & 2.90 \\
\hline Clay & 54.5 & $\mathrm{Na}^{+}$ & 0.93 \\
\hline Textural class & Clay & $\mathrm{K}^{+}$ & 0.72 \\
\hline Field capacity, $\%$ & 45.6 & $\mathrm{HCO}_{3}^{-}$ & 2.36 \\
\hline Wilting point, $\%$ & 4.03 & $\mathrm{Cl}^{-}$ & 1.23 \\
\hline $\mathrm{CaCO}_{3}, \mathrm{~g} \mathrm{~kg}^{-1}$ & 11.4 & $\mathrm{SO}_{4}^{2-}$ & 2.01 \\
\hline $\mathrm{OM}, \mathrm{g} \mathrm{kg}^{-1}$ & 9.40 & Total macronutrient, $\%$ & \\
\hline $\mathrm{CEC}, \mathrm{cmol}_{\mathrm{c}} \mathrm{kg}^{-1}$ & 43.9 & $\mathrm{~N}$ & 0.18 \\
\hline $\mathrm{pH}(1: 2.5)$ & 7.45 & $\mathrm{P}$ & 0.03 \\
\hline $\mathrm{EC}_{\mathrm{e}}, \mathrm{dS} \mathrm{m}^{-1}$ & 0.46 & $\mathrm{~K}$ & 1.49 \\
\hline
\end{tabular}

Carbonate ions were not detected.

Egypt. J. Soil Sci. 58, No. 2 ( 2018 ) 
Potato tuber seeds (Solanum tuberosum, cv. Spunta) were obtained from Agriculture Research Center. Potassium humate solution was purchased from FAM Company for agricultural development (Grandy solution). Potassium humate (powder) and sulphate (granules) were obtained from Agriculture Research Center. Characteristics of the investigated $\mathrm{K}$ fertilizers are shown in Table 2. Tuber seeds of potatoes were sown on the $29^{\text {th }}$ and $27^{\text {th }}$ of October 2014 and 2015, respectively, in rows of $80 \mathrm{~cm}$ width and $50 \mathrm{~cm}$ between hills. The experiment was laid out in a split-plot design with three replications. The main plots were assigned to the irrigation treatments $(50,75$ and $100 \%$ of IR) and the subplots were assigned to the different sources of $\mathrm{K}$ fertilization which were applied after one month of cultivation (i.e. potassium humate or sulphate amended to soils at a rate of $1 \mathrm{~g} /$ plant, potassium humate as ground application at a rate of $0.5 \mathrm{~g} /$ plant plus foliar application of potassium humate at a rate of $2.5 \mathrm{~cm}^{3} / \mathrm{L} /$ plant, and potassium sulphate amended to soils at a rate of $0.5 \mathrm{~g} /$ plant plus potassium sulphate solution sprayed on plants at a rate of $0.25 \mathrm{~g} / \mathrm{L} /$ plant as foliar application). Treatments that contained foliar application were added through two irrigation periods in the same week. All plants received the recommended doses of $\mathrm{N}$ and $\mathrm{P}$ fertilizers according to the Ministry of Agriculture i.e. 240 $\mathrm{kg} \mathrm{P} \mathrm{ha}{ }^{-1}$ in the form of ordinary superphosphate amended before cultivation and $360 \mathrm{~kg} \mathrm{~N} \mathrm{ha}^{-1}$ in the form of ammonium sulphate 30 days amended after plant cultivation.

Flow meter was installed for each irrigation level treatment; two meters were left between each two irrigation levels; plants were irrigated by using drippers of $4 \mathrm{~L} \mathrm{~h}^{-1}$ capacity. Calculations of irrigation levels were performed whereas the irrigation control was practiced via manual valves for each experimental plot. The total amount of irrigation requirement was calculated by FAO, Penman-Monteith procedure (Alva, 2008). The potential evapotranspiration was calculated as follows:

$E T_{o}=\frac{0.408 \Delta\left(R_{n}-G\right)+\gamma \frac{900}{T+273} u_{2}\left(e_{s}-e_{a}\right)}{\Delta+\gamma\left(1+0.34 u_{2}\right)}$

Where:

$\mathrm{ET}_{0}=$ Daily reference evapotranspiration $\left(\mathrm{mm} \mathrm{day}^{-1}\right)$, $\mathrm{R}_{\mathrm{n}}{ }_{\mathrm{n}}=$ Net radiation at the crop surface $\left(\mathrm{MJ} \mathrm{m}^{-2}\right.$ day $\left.^{-1}\right)$, $\mathrm{G}=$ Soil heat flux density $\left(\mathrm{MJ} \mathrm{m}^{-2}\right.$ day $\left.^{-1}\right)$,

$\mathrm{T}=$ Mean daily air temperature at $2 \mathrm{~m}$ height $\left({ }^{\circ} \mathrm{C}\right)$,

$\mathrm{u}_{2}=$ Wind speed at $2 \mathrm{~m}$ height $\left(\mathrm{m} \mathrm{s}^{-1}\right)$,

$\mathrm{e}_{\mathrm{s}}=$ Saturation vapor pressure $(\mathrm{kPa})$,

$\mathrm{e}_{\mathrm{s}}=$ Actual vapor pressure $(\mathrm{kPa})$,

$\Delta=$ The slope of vapor pressure curve $\left(\mathrm{k} \mathrm{Pa}^{\circ} \mathrm{C}^{-1}\right)$, $\gamma=$ The psychometric constant $\left(\mathrm{k} \mathrm{Pa}^{\circ} \mathrm{C}^{-1}\right)$.
The second step was to obtain values of crop water consumptive use $\left(\mathrm{ET}_{\text {crop }}\right)$ as described by Alva (2008); it was calculated as the following:

$$
\mathrm{ET}_{\text {crop }}=\mathrm{ET}_{\mathrm{o}} \mathrm{K}_{\mathrm{c}} \quad \mathrm{mm} / \mathrm{day} \ldots . .
$$

Where:

$\mathrm{ET}_{\mathrm{o}}=$ The rate of evapotranspiration from an excessive surface of green cover of uniform height ( 8 to $15 \mathrm{~cm}$ ), actively growing, completely shading the ground and did not suffer from water shortage.

$\mathrm{K}_{\mathrm{c}}=$ Crop coefficient (ranged from 0.6 to 1.2 ).

Irrigation requirements (IR) were calculated as follow, see Table 3.

$\mathrm{IR}=\mathrm{ET}_{\text {crop }} \times \% \mathrm{LR} \times \mathrm{R} \times 10000 / 1000\left(\mathrm{~m}^{3} / \mathrm{ha} /\right.$ day) (3)

Where:

LR $\%=$ Leaching requirement percentage (22\% of the water requirement based on the leaching fraction equation).

$\mathrm{R}=$ Reduction factor for drip irrigation that only covers a part of land and the rest dry leaves. It was recommend by Alva (2008) to use R value which ranged between 0.25 and 0.90 for drip irrigation system.

At the physiological maturity growth stage i.e. $10^{\text {th }}$ and $14^{\text {th }}$ of February 2015 and 2016, respectively, whole plants were harvested and the total yield of tubers was estimated in ton $\mathrm{ha}^{-1}$ for each treatment. Plant samples were collected to determine the plant height, number of stems per plant, haulm fresh weight, number of tubers per plant and specific gravity of tubers. The specific gravity of tubers was determined following underwater weight method using $2.5 \mathrm{~kg}$ of medium sized tuber by the following equation by Nissen (1967):

Specific gravity $=$ the weight of the tuber in air/ (weight of the tuber in air - its weight in water)

Tubers and haulm samples were digested using a mixture of $\mathrm{H}_{2} \mathrm{SO}_{4} / \mathrm{H}_{2} \mathrm{O}_{2}$ according to the method described by Page et al. (1982). Total nitrogen was determined by Kjeldahl method according to the procedure described by Chapman and Pratt (1961). Phosphorus content was determined using Spectrophotometer according to Watanabe and Olsen (1965). Potassium content was determined photometrically using Flame photometer as described by Chapman and Pratt (1961). 
TABLE 2. Some characteristics of the studied treatments

\begin{tabular}{lccccc}
\hline Treatment & $\mathbf{p H ~ ( 1 : 5 )}$ & $\mathbf{E C}_{\mathbf{e}}, \mathbf{d S ~ \mathbf { ~ m } ^ { - \mathbf { 1 } }}$ & Total N, $\%^{\text {Total P, } \%}$ & Total K, \% \\
\hline Potassium Humate (Powder) & 9.11 & 21.6 & 10.5 & 0.003 & 2.47 \\
Potassium Humate (Solution) & 6.94 & 0.22 & 0.98 & 0.40 & 0.19 \\
Potassium Sulphate (Granules) & 6.50 & 162 & n.d & n.d & 48.0 \\
\hline
\end{tabular}

*n.d means not detected.

TABLE 3. The average of weekly irrigation water requirements under different irrigation water levels for potato plants at the studied site

\begin{tabular}{|c|c|c|c|c|c|c|}
\hline \multirow{3}{*}{$\begin{array}{l}\text { Weeks after } \\
\text { planting }\end{array}$} & \multicolumn{3}{|c|}{$1^{\text {st }}$ season, 2014/ 2015} & \multicolumn{3}{|c|}{$2^{\text {nd }}$ season, 2015/ 2016} \\
\hline & \multicolumn{3}{|c|}{$\mathbf{m}^{3} \mathbf{h a}^{-1}$} & \multicolumn{3}{|c|}{$\mathrm{m}^{3} \mathbf{h a}^{-1}$} \\
\hline & $50 \%$ & $75 \%$ & $100 \%$ & $50 \%$ & $75 \%$ & $100 \%$ \\
\hline 1 & 68 & 102 & 136 & 63 & 95 & 126 \\
\hline 2 & 70 & 106 & 141 & 66 & 100 & 133 \\
\hline 3 & 74 & 111 & 148 & 70 & 105 & 140 \\
\hline 5 & 84 & 127 & 169 & 83 & 124 & 165 \\
\hline 6 & 96 & 145 & 193 & 90 & 135 & 180 \\
\hline 7 & 100 & 150 & 200 & 93 & 140 & 187 \\
\hline 8 & 103 & 155 & 206 & 102 & 154 & 205 \\
\hline 12 & 125 & 188 & 251 & 124 & 187 & 249 \\
\hline 13 & 121 & 182 & 243 & 121 & 182 & 242 \\
\hline 14 & 119 & 179 & 238 & 113 & 169 & 225 \\
\hline 15 & 127 & 191 & 254 & 115 & 172 & 229 \\
\hline 16 & 112 & 169 & 225 & 105 & 158 & 211 \\
\hline 17 & 91 & 137 & 182 & 90 & 135 & 181 \\
\hline 18 & 76 & 115 & 153 & 77 & 116 & 154 \\
\hline 19 & 71 & 107 & 143 & 62 & 93 & 125 \\
\hline 20 & 57 & 85 & 113 & 59 & 88 & 117 \\
\hline
\end{tabular}

Soil samples $(0-30 \mathrm{~cm})$ were collected from the rhizosphere after plant harvest. These samples were air dried and grounded to pass through a 2 $\mathrm{mm}$ sieve. The grounded samples were analyzed for their contents of different $\mathrm{K}$ fractions, i.e. water soluble, exchangeable, non-exchangeable/ fixed in the lattice structure of clay minerals and total K. Water soluble $\mathrm{K}\left(\mathrm{H}_{2} \mathrm{O}-\mathrm{K}\right)$ was extracted by shaking $2.5 \mathrm{~g}$ soil in $50 \mathrm{~mL}$ deionized water for 30 minutes (Habib et al., 2014). Exchangeable K was extracted with 1.0 M NH $\mathrm{OAC}_{4}$ (Knudsen et al., 1982). Non-exchangeable K was extracted with boiling 1.0 $\mathrm{M} \mathrm{HNO}_{3}$ (Martin and Sparks, 1983). Total $\mathrm{K}$ in soils was estimated by digesting soil samples using a mixture of $\mathrm{H}_{2} \mathrm{SO}_{4} / \mathrm{H}_{2} \mathrm{O}_{2}$ according to the method described by Page et al. (1982).

Water use efficiency (WUE) was calculated according to Cantore et al. (2014) as the ratio between the crop yield (Y) and the amount of water for irrigation throughout the growth season (IR).

$$
\text { WUE }\left(\mathrm{kg} \mathrm{m}^{-3}\right)=\mathrm{Y}(\mathrm{kg}) / \mathrm{IR}\left(\mathrm{m}^{3}\right)
$$

The obtained data were then statistically analyzed using SAS software package. The means that were significant were separated using Duncan's multiple range test at $\mathrm{P} \leq 0.05$ (SAS, 2000). 


\section{$\underline{\text { Results and Discussion }}$}

Potassium fractions in soil as affected by the different $K$ sources and irrigation water levels Water soluble $K$

Data illustrated in Fig. 1 showed that the soluble $\mathrm{K}$ increased in soils in the following descending order: humate $>$ sulphate $>$ humate plus humate spray $>$ sulphate plus sulphate spray $>$ control. On the other hand, the concentrations of water soluble $\mathrm{K}$ decreased in soils with increasing the level of irrigation water. This might be attributed to leachability of $\mathrm{K}$ from soil surfaces owing to the increases in irrigation water level. Probably, the dilution effect of soluble soil-K with increasing soil moisture accounted for such reductions. Humate treatment combined with $50 \%$ irrigation water level of IR recorded the highest increase in water soluble $\mathrm{K}$ (72\%), followed by the sulphate treatment combined with $50 \%$ of IR, recording $61 \%$ increase. Wang and Huang (2001) found that application of humic substances prevent $\mathrm{K}^{+}$ions from leaching due to the influence of functional groups commonly present in humic acid (HA), including carboxyl, phenol and hydroxyl, which contributed in $\mathrm{K}^{+}$binding by HA.

\section{Exchangeable $K$}

The values of exchangeable $\mathrm{K}$ are depicted in Fig. 2. It was found that soils amended with either humate or sulphate under $50 \%$ of IR recorded the highest increases in the fraction of exchangeable K. Such increases were 21 and 10\%, respectively, compared to the control. This might take place because $\mathrm{K}$-humate is a soluble $\mathrm{K}$ source that is readily available to be absorbed by the cultivated plants (Sparks, 2000), while on the other hand, this treatment decreased $\mathrm{K}$ fixation by clay minerals (Bansal, 2000). Increasing the irrigation water level from 75 to $100 \%$ of IR led to significant reduction in the exchangeable $\mathrm{K}$ fraction, while on the other hand, decreasing soil moisture from 75 to $50 \%$ of IR recorded no significant effect on this fraction.

\section{Potassium fixed by clay minerals or difficult to exchange}

It seems that the soil and foliar applications of humate or sulphate recorded no significant effect on the non-exchangeable $\mathrm{K}$ content as compared to the control treatment (Fig. 3). Likewise, increasing the level of water irrigation seemed to be of no further significant effect on the nonexchangeable $\mathrm{K}$ content. The forms of soil $\mathrm{K}$ can be arranged according to their availability to plants and microbes as follows: solution > exchangeable $>$ fixed/ non-exchangeable (Sparks, 2000). Thus, the non-exchangeable $\mathrm{K}$ content is thought to be the soil reservoir of $\mathrm{K}$ (Mengel \& Uhlenbecker 1993 and Cox et al., 1999) that releases in more available forms when the levels of soluble and exchangeable $\mathrm{K}$ decreased in soils by plant uptake and soil leaching (Martin and Sparks, 1983). Higher non-exchangeable contents of $\mathrm{K}$ were observed in soils of high clay and silt contents (Tiwari and Nigam, 1994). In such soils, the degree of $\mathrm{K}$ fixation depends on many factors e.g. the type of clay mineral, its charge density, the degree of interlayering, the moisture content, the concentration of competing cations, and the $\mathrm{pH}$ of the ambient solution bathing the clay or soil (Sparks, 2000).

\section{Total K}

The results indicated that little changes occurred in the total content of $\mathrm{K}$ in the studied soil due to the effect of different applied $\mathrm{K}$ sources and irrigation water levels, especially for humate or sulphate plus foliar spray combined with 50 or $75 \%$ irrigation water from IR, with the same trend of non-exchangeable K (Fig. 4). Total $\mathrm{K}$ depends on the presence of $\mathrm{K}$ bearing primary and secondary minerals in the soil. Clay mineralogy is a key factor affecting dynamics of $\mathrm{K}$ in the soils (Ghiri and Abtahi, 2011). Also, the results reported that organic source of $\mathrm{K}$ increased total $\mathrm{K}$ in the studied soil (Fig. 4).

Productivity of potato plants as affected by the different $K$ sources and irrigation water levels Vegetative growth parameters

Table 4 reveals that increasing the level of water irrigation was associated to concurrent increases in plant height, number of stems per plant, haulm fresh and dry weights during both seasons of study. Increasing soil moisture content probably decreased soil salinity (via salt leaching), and thus improved soil environmental conditions in the rhizosphere to become more favourable for encouraging plant growth. On the other hand, low irrigation level or drought stress conditions decreased plant growth probably through the reductions that occurred in root extension while increasing leaf thickness as an adaptation mechanisms towards low soil moisture content (Hashem, 2007). Regarding the effect of K sources on plant growth parameters, soil application of K-humate, followed by K-sulphate recorded the highest increases in such vegetative growth characteristics. Humic acid chelate $\mathrm{K}^{+}$ions and therefore, minimizes their fast transformations to more complexed forms (Bocanegra et al., 2006). Also, $\mathrm{K}$ in form of potassium sulphate is readily available to uptake with plant roots (Ayeni and Adeleye, 2014). The interaction among the studied treatments showed that water irrigation up to $100 \%$ of IR with K in the organic form applied as ground application recorded the highest increases in plant growth parameters. 


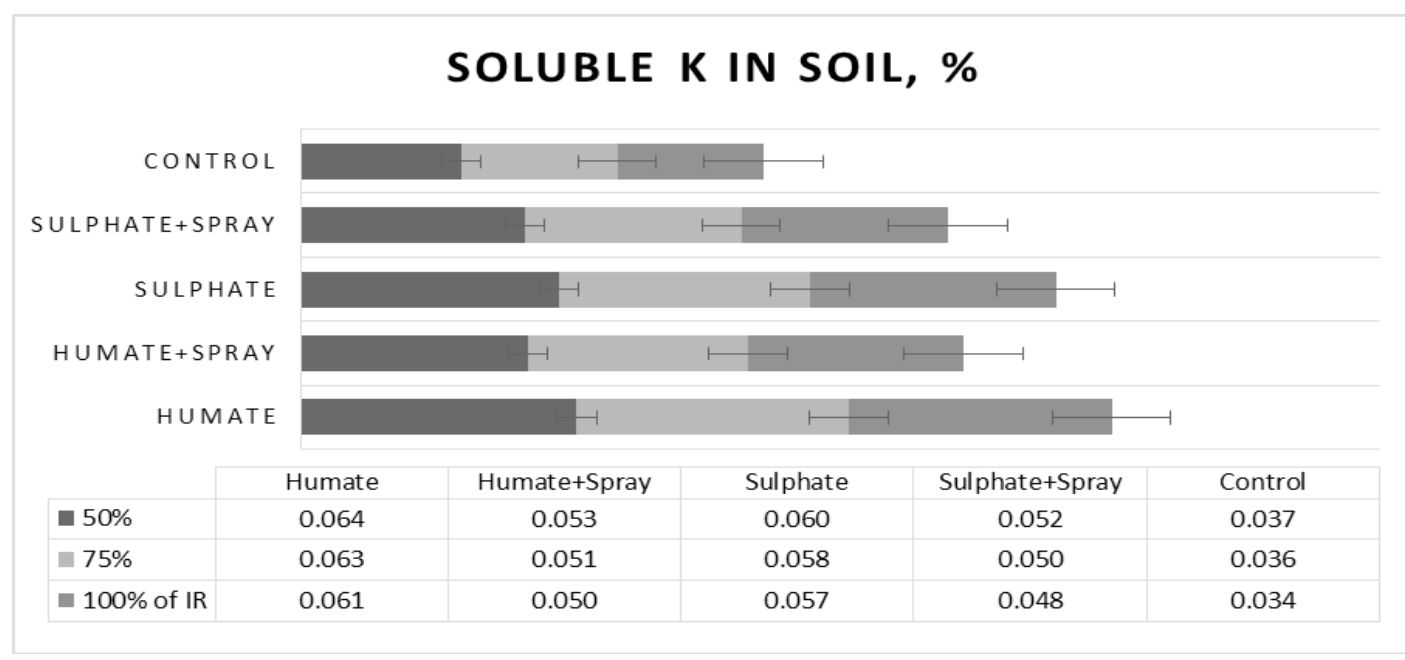

*Each value was the mean of 6 replications during the two studied seasons.

Fig. 1. Effect of different $K$ sources and irrigation water levels on soluble $K$ in the studied soil

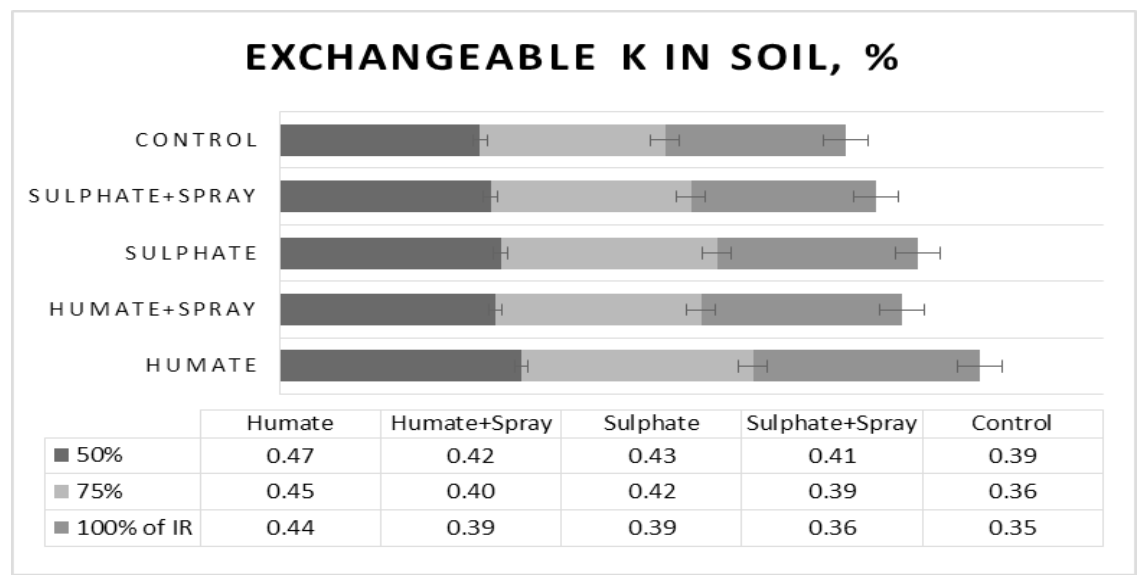

"Each value was the mean of 6 replications during the two studied seasons.

\section{Fig. 2. Effect of different $K$ sources and irrigation water levels on exchangeable $K$ in the studied soil}

\section{Elemental content of haulm}

Nitrogen, phosphorus and potassium contents in potato haulm decreased significantly during both seasons with increasing the level of water irrigation (Table 5). Such reductions might be because of the increment of nutrient movements toward fruits/ tubers or other plant organs. These results agree with those obtained by Hashem (2007) on cucumber. Regarding the effect of the type of K fertilizers on NPK content within plant haulm, the results indicate that K-humate increase $\mathrm{N}$ concentration in potato haulm and this probably attributed to its high content of total $\mathrm{N}$ (Table 2). The treatment of K-humate plus humate foliar spray resulted in the highest increases in $\mathrm{P}$ and $\mathrm{K}$ concentrations in haulm. It is obvious that $\mathrm{K}$ in the organic form increased $\mathrm{N}, \mathrm{P}$ and $\mathrm{K}$ concentrations in haulm exceeding those obtained by $\mathrm{K}$ in mineral addition. The interaction between the source of $\mathrm{K}$ and the irrigation level reveals that the soil application of K-humate recorded the highest increases in N-haulm of soils irrigated with $50 \%$ of IR, while the treatment of K-humate plus humate foliar spray under irrigation with $50 \%$ of IR recorded the highest contents of $\mathrm{P}$ and $\mathrm{K}$ in potato haulm. Mosa (2012) found that humic substances can increase the nutrient content of the growing plants, especially of those grown in sandy soils.

\section{Yield measurements}

Data clearly showed gradual significant reduction in the yield measures in line with increasing water stress conditions (Table 6). 


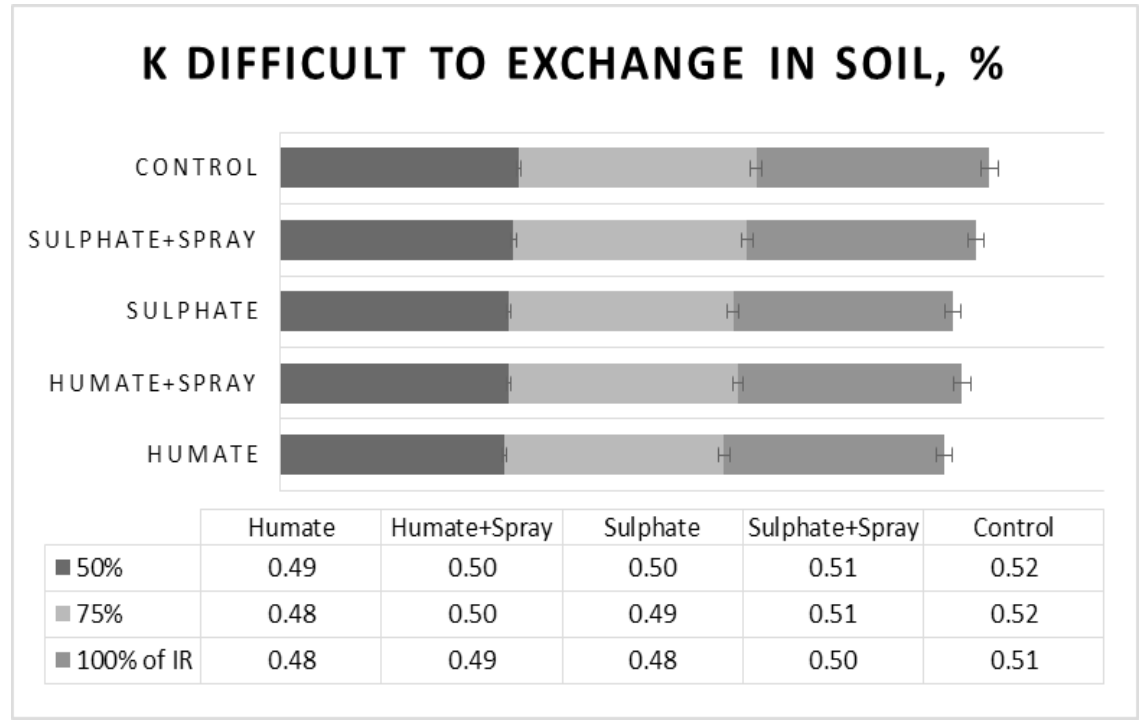

"Each value was the mean of 6 replications during the two studied seasons.

Fig. 3. Effect of different $\mathbf{K}$ sources and irrigation water levels on $\mathbf{K}$ fixed in clay minerals or difficult to exchange in soil

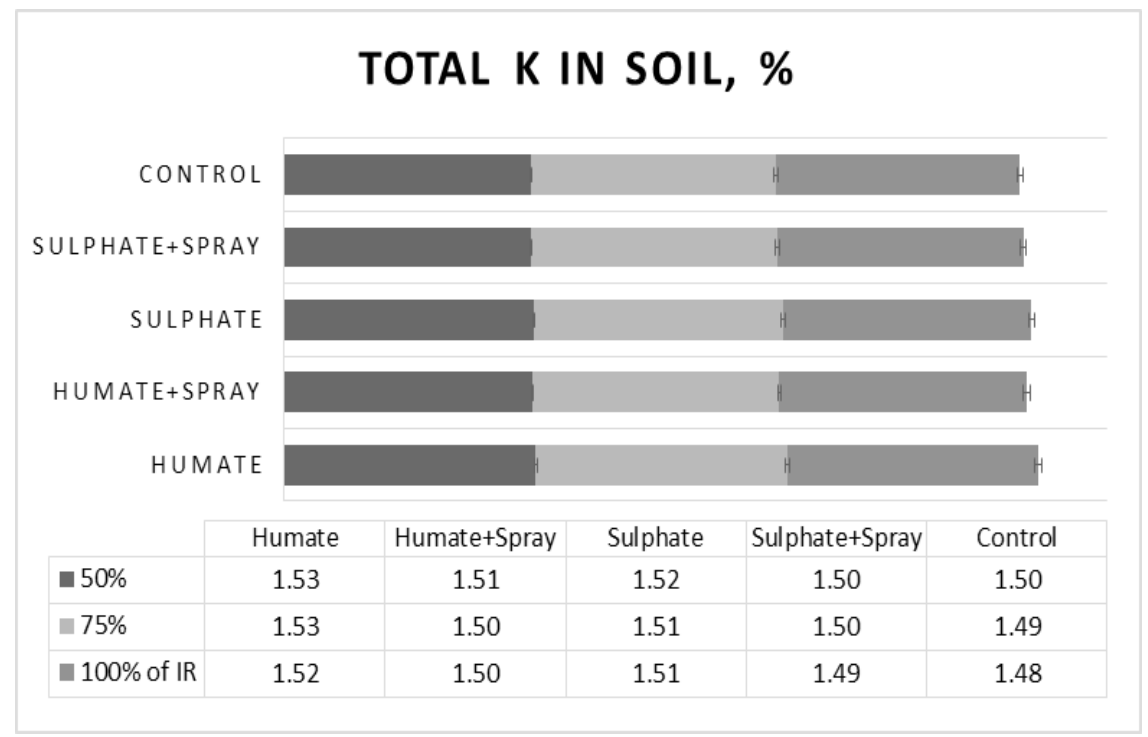

${ }^{*}$ Each value was the mean of 6 replications during the two studied seasons.

Fig. 4. Effect of different $K$ sources and irrigation water levels on total $K$ in the studied soil

The highest decrease was detected at the highest stress level, when water irrigation was supplied at $50 \%$ of IR. Such effect was expected since the adverse effect of decreasing the level of water irrigation was early noticed on most of the plant growth parameters. On the other hand, adequate water supplies up to $100 \%$ of IR promoted the plant growth (Table 4) and resulted in higher yield measures (Table 6). Regarding the effect of the source of $\mathrm{K}$ fertilizers on the yield measures, results showed that soil application of $\mathrm{K}$ in the organic form increased the number of tubers per plant and the outcome yield as compared to the mineral $\mathrm{K}$ form, especially during the second season. Also, the increases in the yield measures that obtained from soil application of K-humate plus humate foliar spray exceeded those attained by the soil application of K-sulphate plus sulphate foliar spray. Regarding the interaction among the studied treatments, $100 \%$ irrigation water level of IR combined with K-humate in the soil was superior in increasing number of tubers per plant and then yield production. 


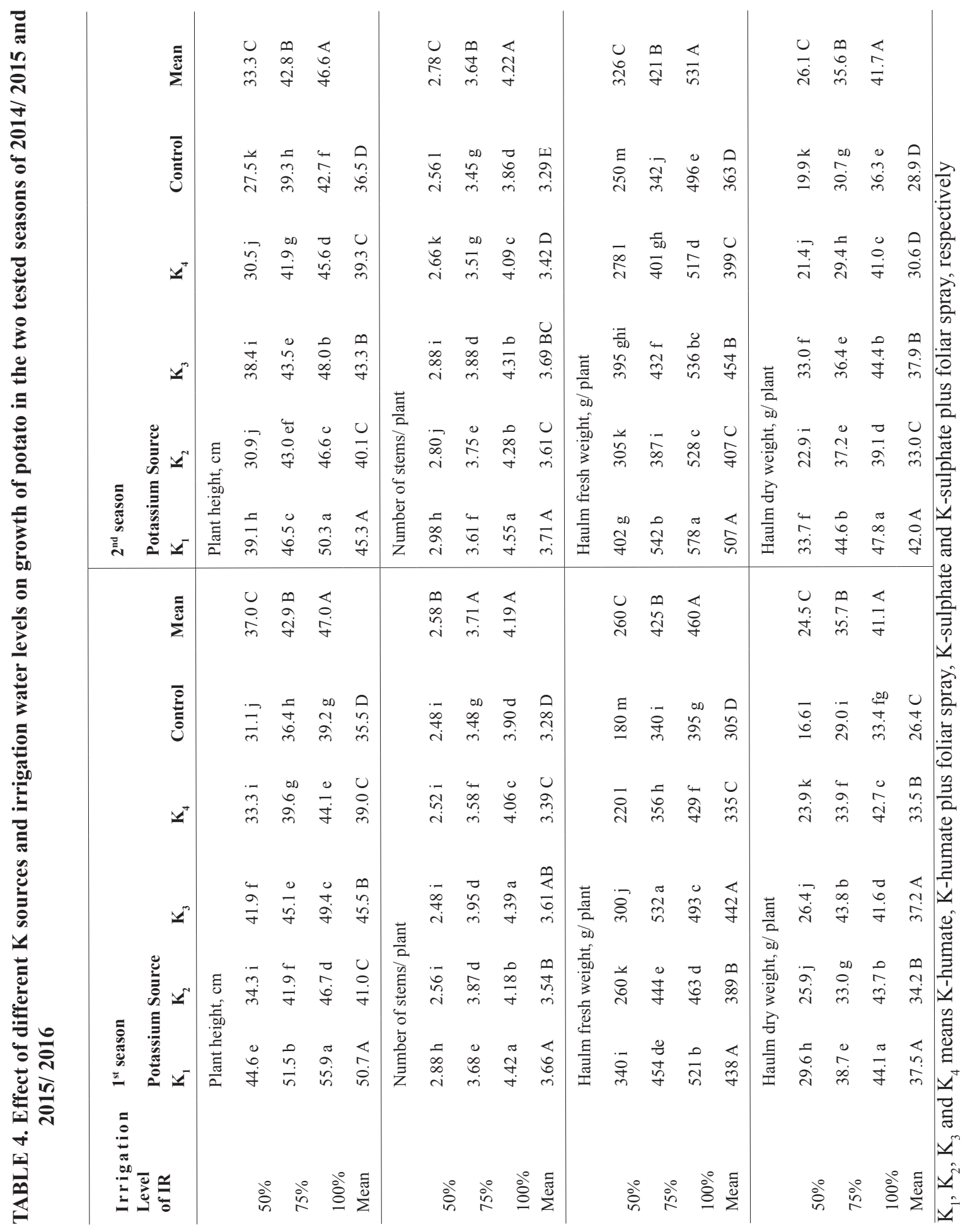




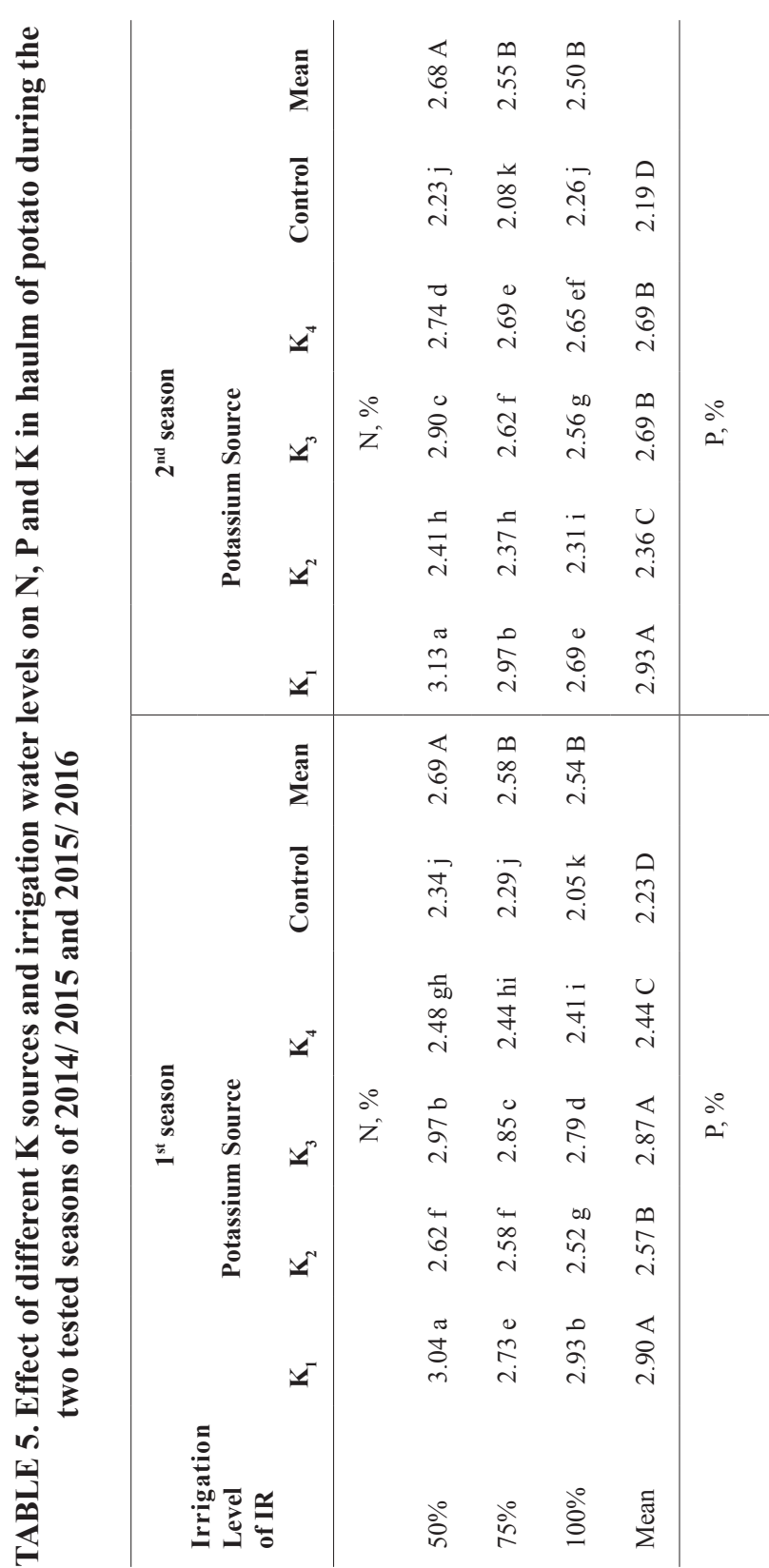

The specific gravity of tuber is an important indicator of potato tuber quality as it indicates the dry matter content of tubers. Generally higher specific gravity indicates higher dry matter content. Elfnesh et al. (2011) found that dry matter content of potato tuber was positively and high significantly correlated with specific gravity $(\mathrm{r}=0.99 * *)$. The maximum specific gravity (1.09 in the two tested seasons) was recorded by applying K-humate in the soil that was irrigated with $50 \%$ of IR, whereas the least ones (1.03 in the two growing seasons) was recorded from control treatment (Table 6). Also, specific gravity of potato tuber increased with increasing nutrient uptake (Table 7). Dasgupta et al. (2017) found

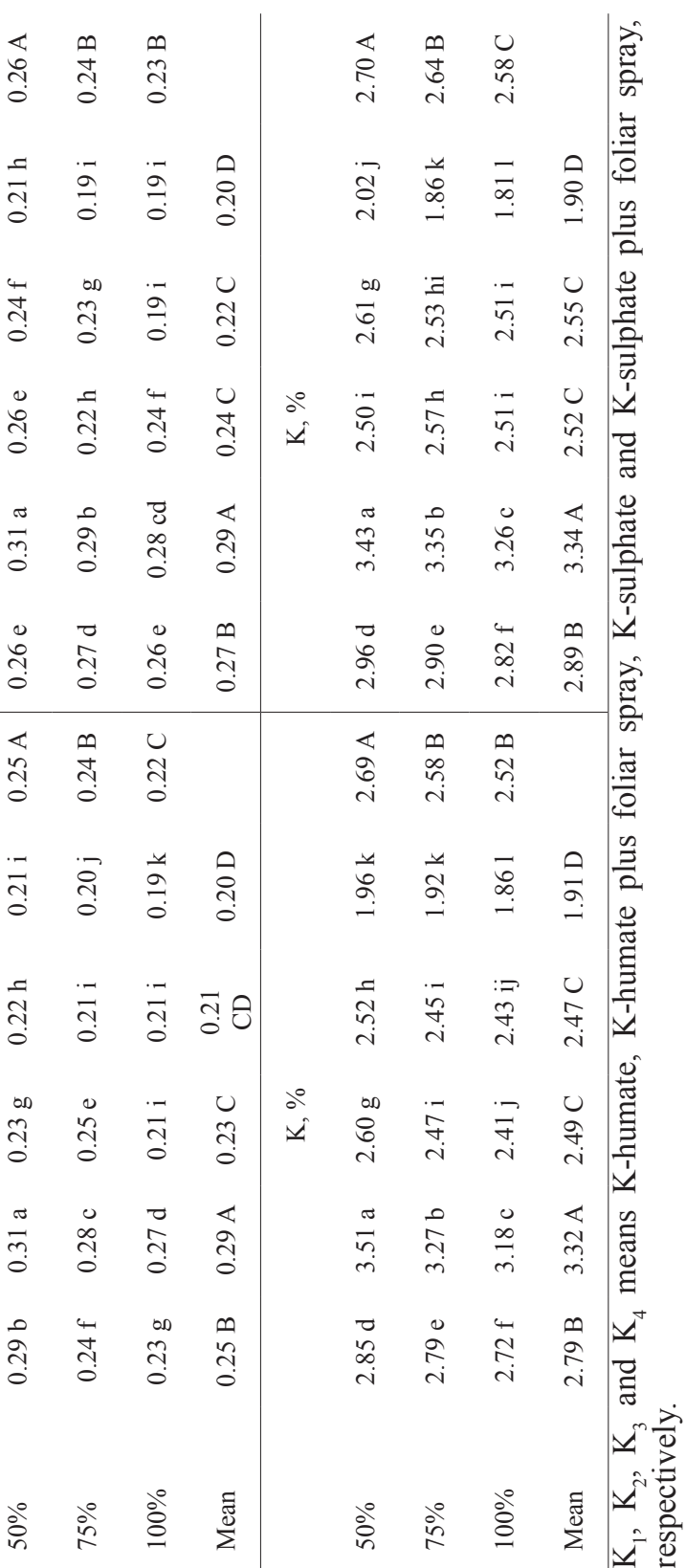

that specific gravity of potato tuber was strongly correlated with nutrients uptake $(\mathrm{r}=0.85,0.88$ and 0.83 for $\mathrm{N}, \mathrm{P}$ and $\mathrm{K}$, respectively). Nutrient contents of $\mathrm{N}, \mathrm{P}$ and specially $\mathrm{K}$ promoted dry matter and starch content of tuber (Acharya, 2006) leading to higher specific gravity of potato.

\section{Elemental content of tubers}

Data shown in Table 7 reveal that N, P and $\mathrm{K}$ concentrations decreased in tubers of potato plants with increasing soil moisture level; however in some cases, no significant differences were detected in $\mathrm{P}$ and $\mathrm{K}$ contents between irrigation levels 75 and $100 \%$ of IR. Regarding the effect of $\mathrm{K}$ sources, amending soils with K-humate recorded 
the highest increases in $\mathrm{N}$ and $\mathrm{P}$ concentrations, followed by soil application of K-humate plus foliar spray in giving high concentration of N. On the other hand, amending soils with K-sulphate resulted in the highest concentration of P. Similar results were found in both seasons of study. This may occur because of the high contents of the investigated nutrients in the studied sources of $\mathrm{K}$ (Table 2). Regarding $\mathrm{K}$ concentration in tubers, the treatment of K-humate as soil application plus spray from a solution containing K-humate as foliar application gave the highest values in the two tested seasons, followed by the treatment of K-humate only as ground application. The interaction between irrigation levels and $\mathrm{K}$ sources showed that the 50\% irrigation level of IR combined with K-humate gave the highest values of $\mathrm{N}$ and $\mathrm{P}$. While $75 \%$ of IR in the first season and $50 \%$ of IR in the second season combined with K-humate plus foliar spray gave the highest values of $\mathrm{K}$ concentration in potato tubers.

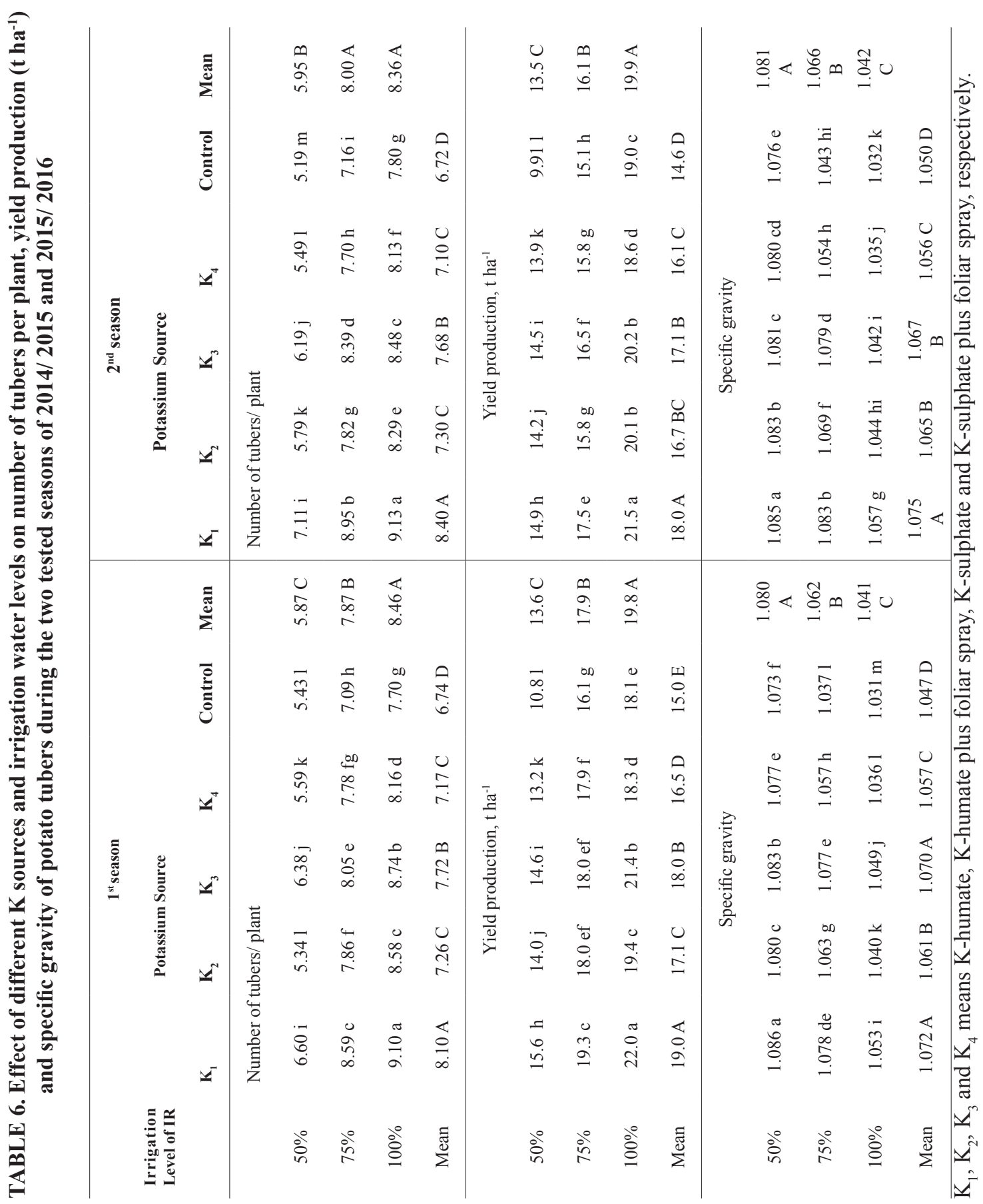

Egypt. J. Soil Sci. 58, No. 2 ( 2018 ) 


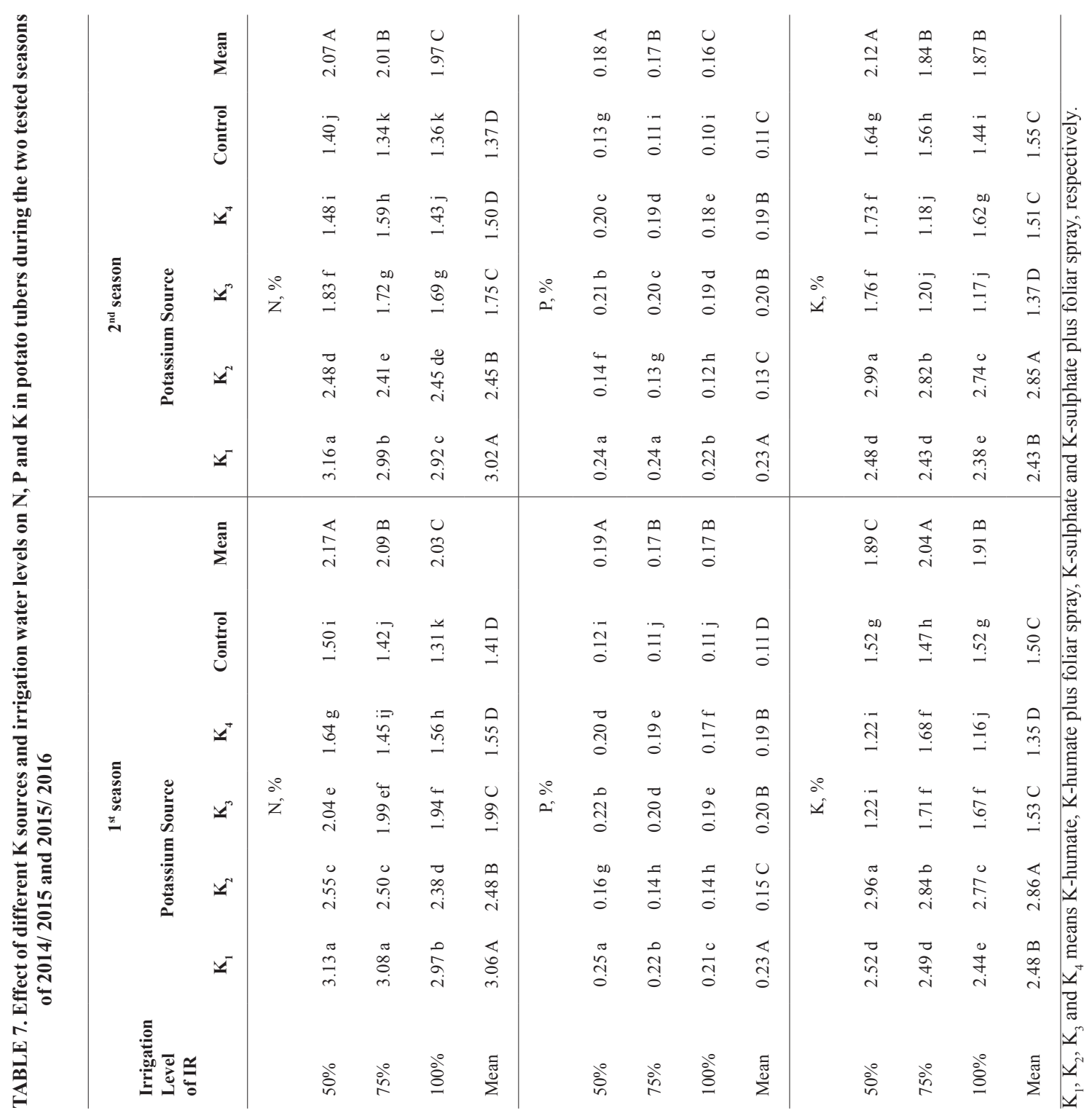

TABLE 8. Effect of different $\mathrm{K}$ sources and irrigation water levels on water use efficiency $\left(\mathrm{kg} \mathrm{m}^{-3}\right)$ for potato plants during the two studied seasons of 2014/ 2015 and 2015/2016

\begin{tabular}{|c|c|c|c|c|c|c|c|c|c|c|c|c|}
\hline \multirow{3}{*}{$\begin{array}{l}\text { Irrigation } \\
\text { Level of } \\
\text { IR }\end{array}$} & \multicolumn{6}{|c|}{$1^{\text {st }}$ season } & \multicolumn{6}{|c|}{$2^{\text {nd }}$ season } \\
\hline & \multicolumn{4}{|c|}{ Potassium Source } & \multirow[b]{2}{*}{ Control } & \multirow[b]{2}{*}{ Mean } & \multicolumn{5}{|c|}{ Potassium Source } & \multirow[b]{2}{*}{ Mean } \\
\hline & $\mathbf{K}_{1}$ & $\mathbf{K}_{2}$ & $\mathbf{K}_{3}$ & $\mathbf{K}_{4}$ & & & $\mathbf{K}_{1}$ & $\mathbf{K}_{2}$ & $\mathbf{K}_{3}$ & $\mathbf{K}_{4}$ & Control & \\
\hline $50 \%$ & 7.99 a & $7.15 \mathrm{c}$ & $\begin{array}{c}7.51 \\
\mathrm{~b}\end{array}$ & $6.77 \mathrm{~d}$ & $5.55 \mathrm{~h}$ & $6.99 \mathrm{~A}$ & $7.62 \mathrm{a}$ & $7.28 \mathrm{c}$ & $\begin{array}{c}7.45 \\
\mathrm{~b}\end{array}$ & $7.13 \mathrm{~d}$ & $5.08 \mathrm{j}$ & $6.91 \mathrm{~A}$ \\
\hline $75 \%$ & $6.61 \mathrm{e}$ & $6.14 \mathrm{f}$ & $6.14 \mathrm{f}$ & $6.11 \mathrm{f}$ & $5.49 \mathrm{i}$ & $6.10 \mathrm{~B}$ & $5.98 \mathrm{e}$ & $5.40 \mathrm{~h}$ & $5.63 \mathrm{f}$ & $5.41 \mathrm{~h}$ & $5.14 \mathrm{i}$ & $5.51 \mathrm{~B}$ \\
\hline $100 \%$ & $5.64 \mathrm{~g}$ & $4.98 \mathrm{j}$ & $5.48 \mathrm{i}$ & $4.69 \mathrm{k}$ & 4.641 & $5.08 \mathrm{C}$ & $5.50 \mathrm{~g}$ & $5.14 \mathrm{i}$ & $5.17 \mathrm{i}$ & 4.771 & $4.86 \mathrm{k}$ & $5.09 \mathrm{C}$ \\
\hline Mean & $6.75 \mathrm{~A}$ & $6.09 \mathrm{C}$ & $\begin{array}{c}6.38 \\
\text { B }\end{array}$ & $5.86 \mathrm{D}$ & $5.22 \mathrm{E}$ & & $6.37 \mathrm{~A}$ & $5.94 \mathrm{C}$ & $\begin{array}{c}6.08 \\
\text { B }\end{array}$ & $5.77 \mathrm{D}$ & $5.03 \mathrm{E}$ & \\
\hline
\end{tabular}

$\overline{\mathrm{K}_{1}}, \mathrm{~K}_{2}, \mathrm{~K}_{3}$ and $\mathrm{K}_{4}$ means $\mathrm{K}$-humate, $\mathrm{K}$-humate plus foliar spray, $\mathrm{K}$-sulphate and $\mathrm{K}$-sulphate plus foliar spray, respectively. 
Water use efficiency (WUE)

Increasing irrigation level over $50 \%$ of IR led to significant reductions in WUE (Table 8). These results agree with those obtained by Hashem et al. (2016). There was a significant interaction between irrigation water treatments and applied $\mathrm{K}$ fertilizer for WUE. The highest WUE value was obtained by $50 \%$ irrigation level of IR combined with K-humate as soil application. Importance of these fertilizers for good yield and better utilization of water can be attributed to the role of $\mathrm{K}$ in improving crop resistance to water stress by playing a vital role in osmotic adjustment (Cantore et al., 2014). Mosa (2012) reported that humic substances when applied to soil, they tend to increase moisture retention in the root zone, and therefore can increase WUE.

\section{Conclusion}

The results showed that potassium application improved the water soluble and exchangeable $\mathrm{K}$ in soil. Organic source of $\mathrm{K}$ improved potassium fractions in the studied clay soil. No considerable trend of non-exchangeable and total $\mathrm{K}$ in soil was found among various sources/ methods of application. The treatment of $100 \%$ followed by $75 \%$ irrigation level of IR, with no significant differences in most trials between them, combined with K-humate as ground application improved the vegetative growth and yield parameters of potato plants, compared to mineral source of applied $\mathrm{K}$. Also, $\mathrm{K}$ in the organic form applied to the soil tend to increase moisture retention in the root zone, and therefore increased WUE.

\section{References}

Abd El-Latif, K., Osman, E., Abdullah, R. and Abd El-Kader, N. (2011) Response of potato plants to potassium fertilizer rates and soil moisture deficit. Adv. Appl. Sci. Res. 2, 388-397. Retrieved from http://www.pelagiaresearchlibrary.com/ advances-in-applied-science/vol2-iss $2 /$ AdASR-2011-2-2-388-397. pdf

Acharya, D. (2006) Studies on production potential, quality improvement and fertility build-up of soil under intensive cropping system through integrated nutrient management. Ph. D. Thesis submitted to Bidhan Chandra Krishi Viswavidyalaya, Mohanpur, District Nadia, West Bengal.

Ajalli, J., Vazan, S., Paknejad, F., Ardekani, M.R. and Kashani, A. (2013) Effect of potassium humate on yield and yield components of different potato varieties as a second crop after barley harvest in Ardabil region, Iran. Annals Biol. Res. 4, 85-89.

Alva, A.K. (2008) Water management and water uptake efficiency by potatoes: A review. Archives Agron. Soil Sci. 54, 53-68.

Ayeni, L.S. and Adeleye, O.E. (2014) Mineralization rates of soil forms of nitrogen, phosphorus, and potassium as affected by organo-mineral fertilizer in sandy loam. Adv. Agric. 2014, 1-5. https://doi. org/10.1155/2014/149209

Bansal, S.K. (2000) Dynamics of potassium in soils under cropping and fertilization. Ph. D. Thesis, B.R. Ambedkar University of Agra, India.

Blagoeva, V., Iliev, E., Nikolova, E. (2004) Potatoes - Cultivation, Diseases and Pests, and Storage. Publisher "Enjovche" Sofia. 105 p.

Bocanegra, M.P., Lobartini, J.C. and Orioli, G.A. (2006) Plant uptake of iron chelated by humic acids of different molecular weights. Communes. Soil Sci. Plant Anal. 37, 239-248. https://doi.org/10.1080/00103620500408779

Cantore, V., Wassar, F., Yama, S.S., Sellami, M.H., Albrizio, R., Stellacci, A.M. and Todorovic, M. (2014) Yield and water use efficiency of early potato grown under different irrigation regimes. Int. J. Plant Production 8, 409-428.

Chapman, H.D. and Pratt, P.F. (1961) Methods of Analysis for Soils, Plants and Waters. USA: California, Division of Agric. Sci., Berkeley Univ., 150-152.

Cox, A.E., Joern, B.C., Brouder, S.M. and Gao, D. (1999) Plant available potassium assessment with a modified sodium tetraphenyle boron method. Soil Sci. Soc. Amer. J. 63, 902-911.

Dasgupta, S., Sarkar, A., Chaitanya, A., Saha, A., Dey, A. and Mondal, R. (2017) Response of potato crop to integrated nutrient management in the IndoGangetic alluvial soils of West Bengal, India. J. Exp. Agric. Int. 16, 1-10. https://doi.org/10.9734/ JEAI/2017/33138

Ebert, G. (2009) Potassium nutrition and its effect on quality and post-harvest properties of potato. Proceedings of the International Symposium on Potassium Role and Benefits in Improving Nutrient Management for Food Production, Quality and Reduced Environmental Damages, 1, 637- 638.

Elfnesh, F., Tekalign, T. and Solomon, W. (2011) Processing quality of improved potato (Solanum tuberosum L.) cultivars as influenced by growing environment and blanching. Afr. J. Food Sci. 5, 324-332. 
El-Ramady, H., El-Marsafawy, Samia and Lewis, L. (2013) Sustainable Agriculture and Climate Changes in Egypt. p. 76-77. In: Lichtfouse, E. (Ed.). Sustainable Agriculture Reviews. Springer Sci. https://doi.org/10.1007/978-94007-5961-9_2

Ghiri, M.N. and Abtahi, A. (2011) Potassium dynamics in calcareous vertisols of southern Iran. Arid Land Res. Manage. 25, 257-274.

Habib, F., Javid, S., Saleem, I., Ehsan, S. and Ahmad, Z.A. (2014) Potassium dynamics in soil under long term regimes of organic and inorganic fertilizer application. Soil Environ. 33, 110-115.

Hashem, F.A. (2007) Studies on water requirements and nitrogen fertilization for cucumber under protected cultivation. $M$. Sc. Thesis, Fac. Agric., Ain Shams Univ., Egypt.

Hashem, F.A., Taha, Noura M., and AbdElrahman, Shaimaa H. (2016) Effect of phosphate and potassium fertilizer rates on potato plants grown under water stress conditions. Int. J. Plant Soil Sci. 13, 1-13. https://doi.org/10.9734/IJPSS/2016/28372

Klute, A. (1986) Methods of Soil Analysis, part I, $2^{\text {nd }}$ ed., USA: Madison, Wisconsin.

Knudsen, D., Peterson, G.A. and Pratt, P.F. (1982) Lithium, Sodium and Potassium. p. 225-246. In: Miller, R.H. and Keeney, D.R. (Ed.). Methods of Soil Analysis. Part 2: Chemical and Microbiological Properties. $2^{\text {nd }}$ ed. Soil Sci. Soc. Amer. J., USA: Madison.

Martin, H.W. and Sparks, D.L. (1983) Kinetics of non-exchangeable potassium release from two coastal plain soils. Soil Sci. Soc. Amer. J. 47, 883-887.

Mengel, K. and Uhlenbecher, K. (1993) Determination of available interlayer potassium and its uptake by ryegrass. Soil Sci. Soc. Amer. J. 57, 761-766.

Mosa, A.A. (2012) Effect of the Application of Humic Substances on Yield, Quality, and Nutrient Content of Potato Tubers in Egypt. In: He, Z. et al. (Eds.). Sustainable Potato Production: Global Case Studies. Springer
Sci. Chapter 27, 471-492. https://doi. org/10.1007/978-94-007-4104-1

Nissen, M. (1967) The weight of potatoes in water: Further studies on the relation between the dry matter and starch content. Eur. Potato J. 10, 85-99.

Onder, S., Caliskan, M.E., Onder, D. and Caliskan, S. (2005) Different irrigation methods and water stress effects on potato yield and yield components. Agric. Water Manage. 73, 73-86.

Page, A.L., Miller, R.H. and Keeney, D.R. (1982) Methods of Soil Analysis, part II, $2^{\text {nd }}$ ed., USA: Wisconsin.

Rytel, E., Lisinska, G. and Tajner-Czopek, A. (2013) Toxic compound levels in potatoes are dependent on cultivation methods. ACTA Alimentaria, 42, 308-317.

SAS Institute (2000) The SAS system for windows; Statistical Analysis System Institute Inc., USA: Cary, North Carolina.

Sparks, D.L. (2000) Bioavailability of Soil Potassium, D-38-D-52. In: Sumner, M.E. (Ed.) Handbook of Soil Science, CRC Press, USA: Boca Raton, Florida.

Tiwari, K.N. and Nigam, V. (1994) Forms of potassium in soils of central alluvial region of Uttar Pradesh. J. Potassium Res. 10, 23-31.

Wang, F.L. and Huang, P.M. (2001) Effects of organic matter on the rate of potassium adsorption by soils. Can. J. Soil Sci. 81, 325330.

Watanabe, F.C. and Olsen, S.R. (1965) Test of an ascorbic acid method for determining phosphorus in water and $\mathrm{NaHCO}_{3}$ extracts from soils. Soil Sci. Soc. Amer. Proc. 29, 677678.

Zörb, C., Senbayram, M. and Peiter, E. (2014) Potassium in agriculture - Status and perspectives. J. Plant Physiol. 171, 656-669.

(Received:24/1/2018;: accepted:19/3/2018) 


\title{
مقارنة بين المصادر العضوية والمعدنية للبوتاسيوم وتأثيرها على صور البوتاسيوم في أرض طينية وإنتاجية نباتات البطاطس تحت ظروف المُنة الإجهاد المائي
}

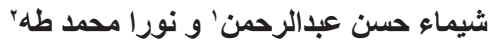

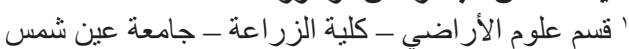

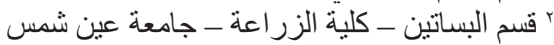

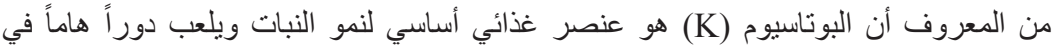

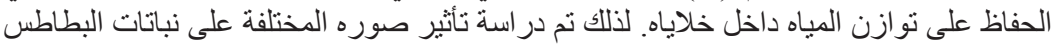

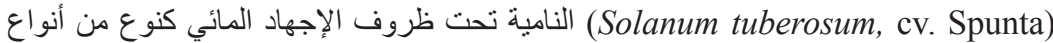

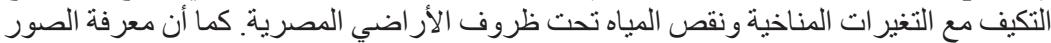

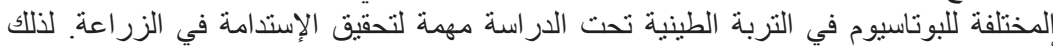

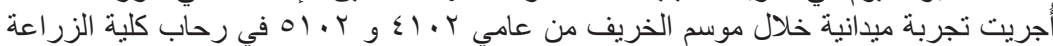

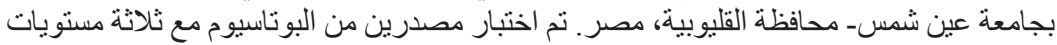

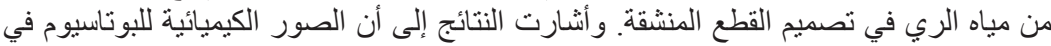

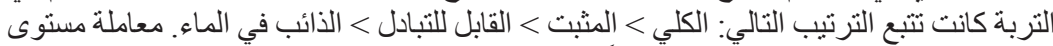

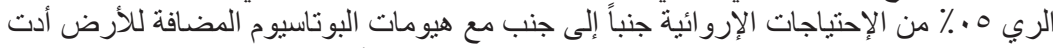

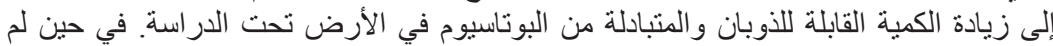

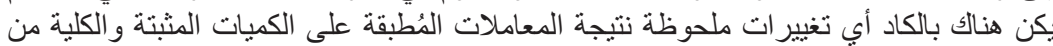

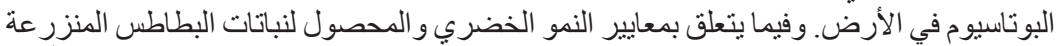

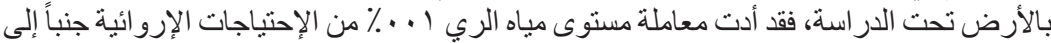

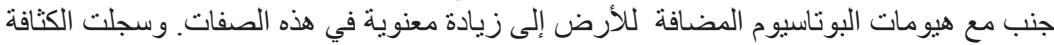

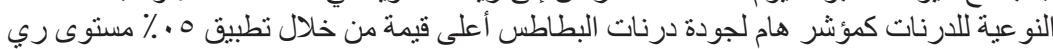

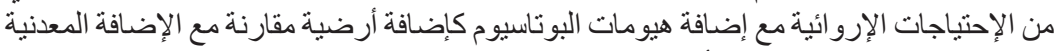

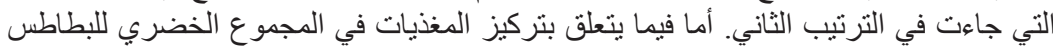

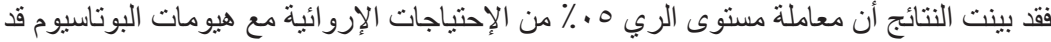

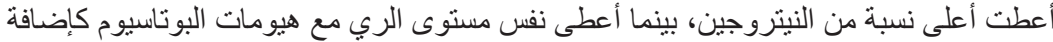

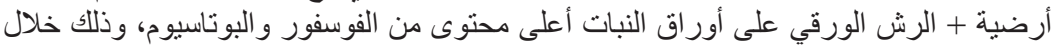

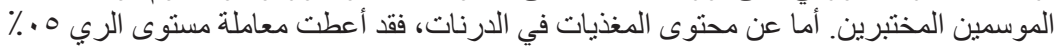

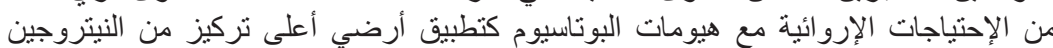

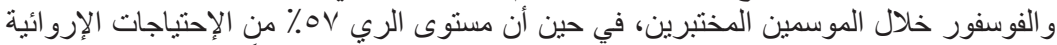

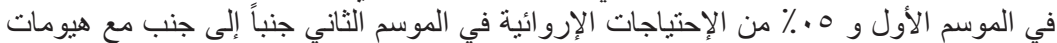

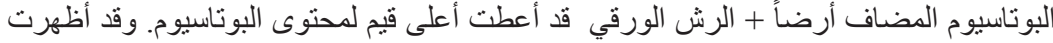

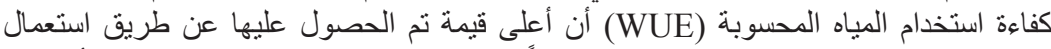

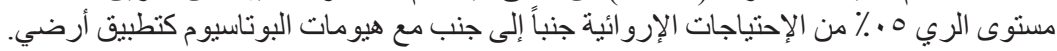

